\title{
COMPETITION ANALYSIS OF IMPORTED AND LOCAL ORANGES
}

\author{
Dini Maulida Rachmi*)1, Rita Nurmalina**), and Amzul Rifin**) \\ *) School of Business, Bogor Agricultural University \\ Pajajaran Road, Bogor 16151 \\ ${ }^{* *}$ Department of Agribusiness, Faculty of Economics and Management, Bogor Agricultural University \\ Jl. Kamper Wing 2 Level 5, Dramaga Campus IPB 16680
}

\begin{abstract}
Indonesia is faced by global competition, in particular for its fruit commodity. Orange a commodity currently prioritized to be developed. The availability of seasonal oranges provides an opportunity for the imported orange products to substitute the local oranges. The objective of this study was to analyze the competition between the local oranges and imported oranges. The analytical method used was Almost Ideal Demand System (AIDS). The results show that the local oranges can compete with the imported oranges from China. It is indicated by the positive cross elasticity value (substitution). The decline in the price of oranges imported from China will reduce the market share of local oranges in Indonesia. Therefore, Indonesia needs to improve the marketing efficiency of its local oranges and increases the local orange production to meet its consumption needs of oranges.
\end{abstract}

Keywords: AIDS, competition, import, oranges, production

\begin{abstract}
Abstrak: Indonesia dihadapkan pada persaingan global, komoditas buah tertentu. Jeruk adalah salah satu komoditas yang saat ini diprioritaskan untuk dikembangkan. Ketersediaan jeruk musiman memberikan kesempatan bagi produk jeruk impor untuk menggantikan jeruk lokal. Tujuan dari penelitian ini adalah untuk menganalisis persaingan antara jeruk lokal dan impor. Metode analisis yang digunakan adalah Almost Ideal Demand System(AIDS). Hasil penelitian menunjukkan bahwa jeruk lokal bersaing dengan impor jeruk dari China. Hal ini dibuktikan dengan nilai elastisitas harga silang positif (substitusi). Penurunan harga jeruk impor dari Cina akan menurunkan pangsa pasar jeruk lokal di Indonesia. Oleh karena itu, Indonesia perlu meningkatkan efisiensi pemasaran jeruk lokal dan meningkatkan produksi jeruk lokal untuk memenuhi kebutuhan konsumsi jeruk di Indonesia.
\end{abstract}

Kata kunci: AIDS, impor, jeruk, persaingan, produksi

\footnotetext{
${ }^{1}$ Corresponding author:

Email: dinimaulidarachmi@gmail.com
}

\section{INTRODUCTION}

Indonesia is a country that is incorporated in regional, multilateral and bilateral agreements. The free trade era requires the readiness of domestic production capability and the ability to improve the competitiveness of its products to compete with the products of other countries. One sector affected by the free trade in Indonesia is the horticulture sub-sector. Indonesia is a potential market for horticultural imported products, as reflected in the negative trade balance of horticultural commodity at US \$-1.176 million in 2014 (Kementan, 2015).

Based on the Strategic Plan of Directorate General of Horticulture from 2015 to 2019 , horticulture commodity continues to grow and develop as a commodity in great demand by consumers. A number of horticultural commodities become a strategic issue that obtains serious attention from the government and business actors include oranges from the fruit group; therefore, activities and their realization will be prioritized on this commodity.

This is similar to the National Socioeconomic Survey (SUSENAS) from 1995 to 2014, the consumption of citrus for household needs tended to increase with an average growth of $11.65 \%$ per year. In addition, the number of citrus production in Indonesia tended to decrease (Figure 1). This indicates that Indonesia has not been able to maintain its production level. 
The volume of imported oranges compared to that of the local oranges production is still relatively small; however, imported oranges are easier to find in supermarkets, traditional markets and retailers (Sayekti and Zamzami, 2011; Hanif and Zamzami, 2012; Nurchayati and Hikmah, 2014). The data of import volume of Indonesian fresh oranges is presented in the following Figure 2.

In 2015, the imported of fresh Indonesian citrus fruits reached 823,130 quintals (Figure 2). Until 2012, the imported oranges showed a positive trend. Subsequently, as an effort to maintain the stability of the domestic horticultural products, the government made regulation on the recommendation towards the import of horticultural products as stated in the Ministerial Regulation Act 86 of 2013. RIPH is a letter issued by the Minister of Agriculture or appointed official and is a condition of the issuance of Import Approval. This regulation aims to improve the effectiveness and efficiency of import management of horticultural products and provide certainty in the RIPH publishing service. The permit of imported oranges is adjusted according to the needs and the harvest season of citrus, so, the number of imported oranges are more efficient. This is reflected in the decline of imported of fresh oranges products in 2013.

The increasing volume of imported fruits will have an economic impact on the competitiveness of local fruits (Firdaus, 2005). The availability of imported citrus abundant in the retail market indicates increasingly unpowered local oranges to compete with imported oranges. In 2015, imported oranges were dominated by the oranges from China reaching $68.61 \%$, and those from Pakistan reached 24.63\% (Tradmap, 2016). Orange/tangerine industry as the local orange industry in Indonesia has been threatened by the existence of imported oranges. The tendency to consume imported oranges may have an impact on the decrease of local orange production. Therefore, an analysis on the level of competition of fresh imported oranges and local oranges was required in order to obtain a good policy recommendation for the government and domestic citrus businessmen in an effort to increase the production of national citrus.

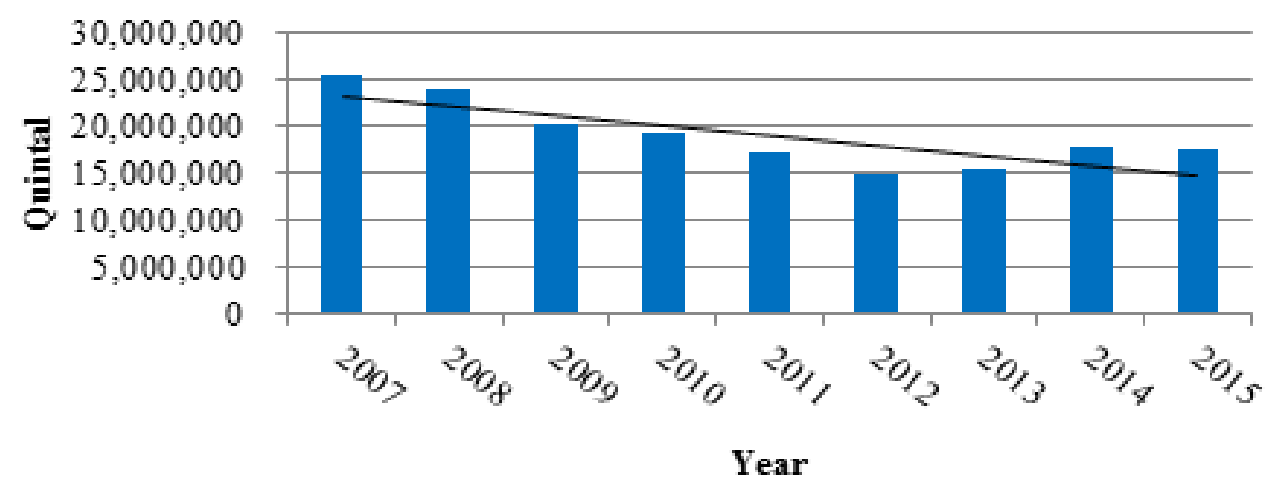

Figure 1. The quantity of citrus production in Indonesia from 2007 to 2015 (BPS, 2016)

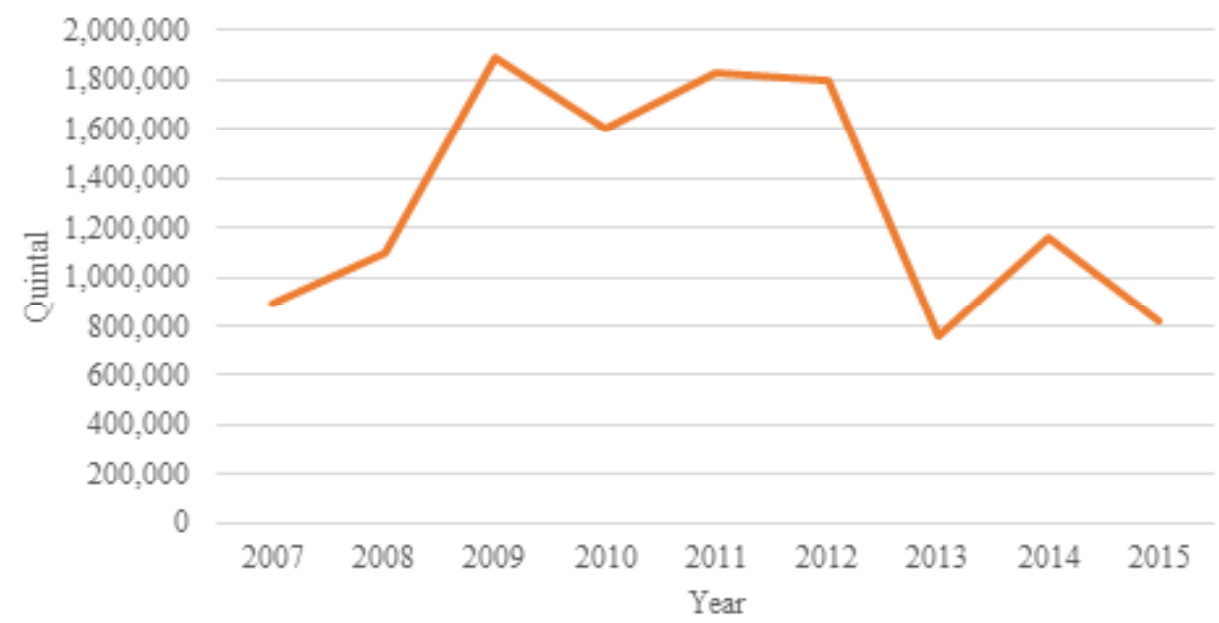

Figure 2. The volume imported of fresh citrus in Indonesia from 2007 to 2016 (BPS, 2016) 
Global competition is a popular topic commonly discussed, as global competition becomes a phenomenon that cannot be avoided by any country. Seale et al. (2012) identifies how global competition has an impact on the domestic market. For example, the analysis on competition in international markets such as from the research by Chang and Nguyen (2002), Rifin (2010), and Hatab and Romstad (2013) shows how export products compete with products from other countries in the international market. Competition is shown from the value of positive cross-price elasticity or it can be said that the products are mutually substituted (Seale et al. 2012; Jamil, 2015; Yuliastuti et al. 2015).

This study was aimed to analyze the level of competition between fresh local oranges and fresh imported oranges in Indonesian citrus market, and to analyze policy alternatives that need to be applied as an effort to increase local citrus production.

\section{METHODS}

The data sources of this research were secondary data. They were based on an econometric model built to answer the research questions. These secondary data were time series data consisting of orange trading data and macroeconomics from 2007 to 2015. Trading data used the imported oranges data with HS-080520 code.

The research instrument to answer the problems related to the competition of imported oranges commodities and domestic production was Almost Ideal Demand System (AIDS). Liner Appoximate/Almost Ideal Demand System (LA/AIDS) was used to estimate price competitions among the imported oranges sources. The advantage of this method is to see competitions among suppliers in an industry (Hui et al. 1996).

The Model Almost Ideal Demand System (AIDS) was first developed by Deaton and Muelbauer (1980). This model can also be used to describe the competition of imported products in the domestic market (Jamil 2015; Destriani et al. 2015). Seale et al. (2002) involves local production in the AIDS equation with the aim to see how the competitiveness of the local products responds to imports. The AIDS model in this study is as follows:

$$
w_{t}=\alpha_{i}+\sum_{i=1}^{n} \gamma_{i j} \ln P_{j}+\beta_{i} \ln \left(\frac{x}{p^{*}}\right)
$$

Notices: $\mathrm{w}_{\mathrm{t}}$ (citrus market share from imported and local sources); $p$ (the price of oranges from each country); $x$ (the total value of Indonesia expenditure on oranges); $\mathrm{p}^{*}($ Stone's geometric price index//wi.pi).

There are three similarities of AIDS models in this study. The three equations are as follows:

$$
\begin{aligned}
\text { Wina }= & \alpha 1+\delta_{1} \operatorname{Ln} \text { Pina }+\delta_{2} \operatorname{Ln} \text { Pcin }+\delta_{3} \operatorname{Ln} \text { Ppak }+\delta_{4} \\
& \operatorname{Ln} \text { Prow }+\beta_{1} \operatorname{Ln}(\mathrm{x} / \mathrm{P} *)+\delta_{4} \mathrm{~d} 1+\delta_{5} \mathrm{~d} 2 \\
\text { Wcin }= & \alpha 2+\delta_{6} \operatorname{Ln} \text { Pina }+\delta_{7} \operatorname{Ln} \text { Pcin }+\delta_{8} \operatorname{Ln} \text { Ppak }+\delta_{9} \\
& \operatorname{Ln} \text { Prow }+\beta_{2} \operatorname{Ln}(\mathrm{x} / \mathrm{P} *)+\delta_{10} \mathrm{~d} 1+\delta_{11} \mathrm{~d} 2 \\
\text { Wpak }= & \alpha 3+\delta_{12} \operatorname{Ln} \text { Pina }+\delta_{13} \operatorname{Ln} P \operatorname{Pcin}+\delta_{14} \operatorname{Ln} \text { Ppak }+ \\
& \delta_{15} \operatorname{Ln} \text { Prow }+\beta_{3} \operatorname{Ln}\left(\mathrm{x} / \mathrm{P}^{*}\right)+\delta_{16} \mathrm{~d} 1+\delta_{17} \mathrm{~d} 2
\end{aligned}
$$

Where: $\alpha 1, \alpha 2, \alpha 3$ (Intercept); $\delta_{1} \ldots \delta_{17}$ and $\beta_{1} \ldots \beta_{3}$ (coefisien); Pina (Indonesian local retail consumer price); Pcin (Orange price (import value per import volume) of China); Ppak (Orange price (import value per import volume) Pakistan); Prow (The price of citrus import sources Rest of World); d1(Dummy Variable, quarterly 1 (Chinese New Year/Imlek) $=1$, others=0); d2 (Dummy Variable, quarterly $3=1$, others $=0$ ).

The regression coefficients on the AIDS model were assumed by the seemingly method Unrelated Regression (SUR). The three equations in this study were limited by using the constraints of homogenity and symmetry, while the adding up properties have been met in the model by itself as an advantage of the AIDS model. The elasticity values are as follows:

Uncompensated Elasticity

$$
e_{i j}=-\delta_{i j}+\frac{\hat{\gamma}_{i j}}{\bar{W}_{i}}-\hat{\beta}_{i} \frac{\bar{W}_{j}}{\bar{W}_{i}}
$$

Compensated Elasticity

$$
e_{i j}^{*}=-\delta_{i j}+\frac{\hat{\gamma}_{i j}}{\bar{W}_{i}}-\bar{W}_{j}
$$

Elasticity of expenditure

$$
\eta_{i}=1+\frac{\hat{\beta}_{i}}{\bar{W}_{i}}
$$

Where: $\delta$ (Knocker delta (where $\delta_{\mathrm{ij}}$ and $\delta_{\mathrm{ij}}$ is for $\mathrm{i}$ which is not the same $\mathrm{j}$ )

Definition of operational as follows:

1. Expenditure on imported citrus is an import value for citrus commodity from each country of origin of import. 
2. Expenditure on local oranges is the total of citrus production multiplied by the price of oranges at the consumer level in the domestic market.

3. The total citrus expenditure refers to the expenditure on local oranges (production volume multiplied by local citrus consumer price) plus import value of Indonesian oranges.

4. Variable dummy 1 explains that in the 1st quarter, there is Chinese New Year/an Imlek event, so the demand for oranges increases.

5. Variable dummy 3 explains that in every 3 rd quarter, each country of orange origin experiences a lean period.

Based on the description of the research background and method of analysis, the frame of thought in this study can be seen in Figure 3. The results of the analysis with competition with Almost Ideal Demand System method will be input in making policy alternatives as an effort to increase local citrus production. Thus, based on the problem and the framework of thinking, the hypothesis used in this research is that the imported orange competes with the local citrus production in Indonesian citrus market.

\section{RESULTS}

\section{Diversity of Local and Imported Oranges}

\section{Local Oranges Production}

If seen from the pattern of production, the production of Siam/tangerine oranges in Indonesia shows a different pattern every year. In general, in the first quarter, orange production in Indonesia tends to decline, but in the second quarter it increases. The pattern of production shown in Figure 4 does not show the same harvest pattern every year, but in Indonesia, there are generally peak harvests in the second and third quarter.

\section{Imported Orange}

The abundance of oranges production in China causes the price of oranges from China to be very low; therefore, they are then exported to a lot of countries in the world including to Indonesia. The development of imported oranges of China is presented in Figure 5.

- Fluctuations in National oranges production

- Growth of import volume of citrus

- Free trade threats

- Price and quality of imported orange is considered superior

- Competition between imported oranges and local oranges

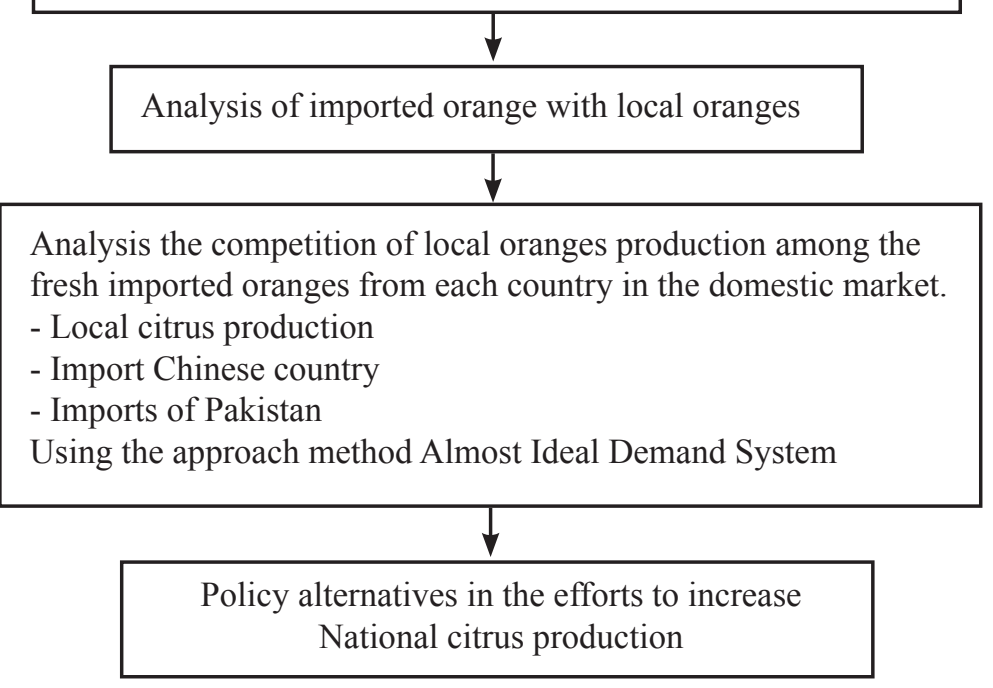

Figure 3. Research framework 
Based on Figure 5, the import of oranges from China shows a certain pattern, and the highest total import was in the first quarter. This is due to the Chinese New Year/ Imlek event occurring in the first quarter, so that the need for oranges in Indonesia increased. In addition, at the beginning and end of the year, China generally reaches its harvest peak; therefore, its abundance becomes an opportunity for China to export its oranges to various countries in the World including to Indonesia.

Kino is the name of Mandarin orange whose market origin is from Pakistan. Kino oranges have the characteristics of fruit with light colors, soft and easy peeling skin, and fresh orange aroma. Kino harvesting season in Pakistan starts from early December to April. As a prime orange commodity in Pakistan, Kino is focused to be developed in International market. The main markets for Kino oranges are the EU and the Asia region including Indonesia as one destination of kino orange export. Imports of oranges from Pakistan show a positive trend (Figure 6). In 2012, Preferential Trade Agreement (PTA) between Indonesia and Pakistan was made where Indonesia is required to remove import duties for Kino oranges from Pakistan; as a result, the import of kino oranges to Indonesia was increasing. This indicates that the imported orange market in Indonesia is shifting when oranges from Pakistan begin to shift the Indonesian market share of fresh orangs from China.

The total of orange imports from other countries was very small when compared with the two countries of origin of imported oranges (China and Pakistan). On the contrary, the cases with China and Pakistan within the third quarter, the total of imports from these countries are equal to zero whereas Indonesia almost every quarter imports oranges from other countries. The difference is due to the orange harvest season in China and Pakistan is almost simultaneous, so the pattern of imports from both countries is the same.

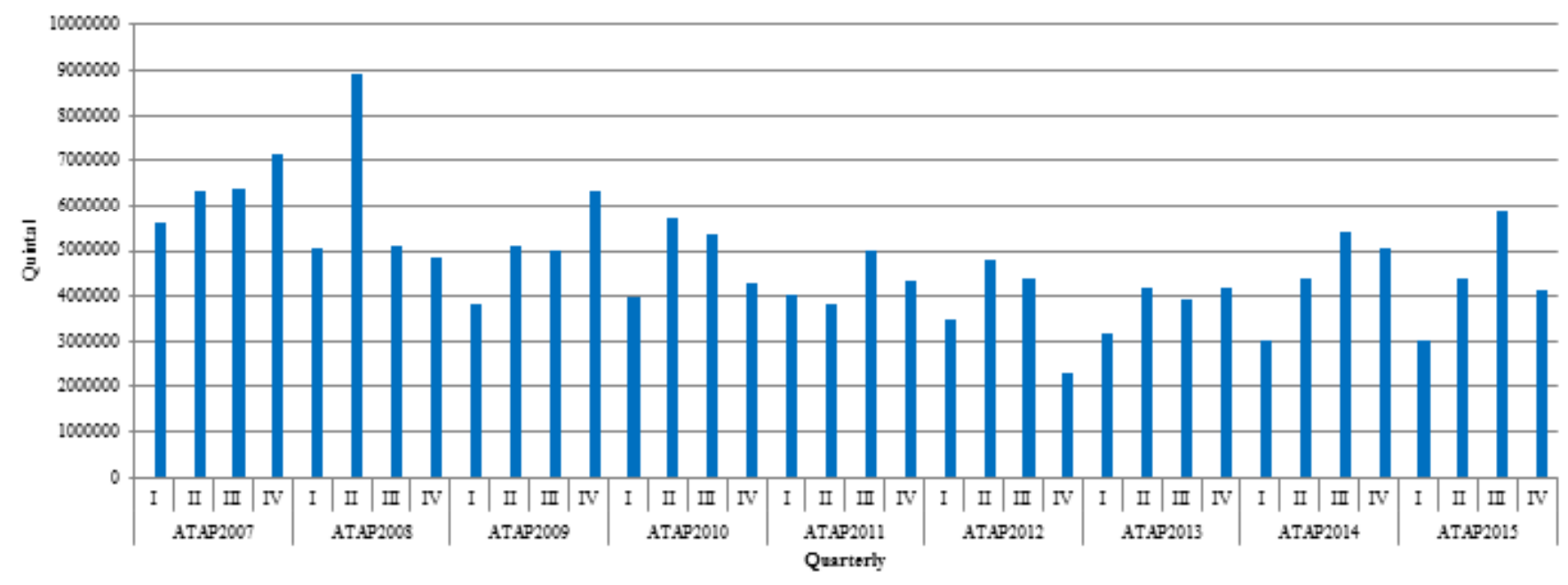

Figure 4. Production of Siam/tangerine per-quarter in Indonesia during 2007-2015 (Ditjen Hortikultura, 2017)

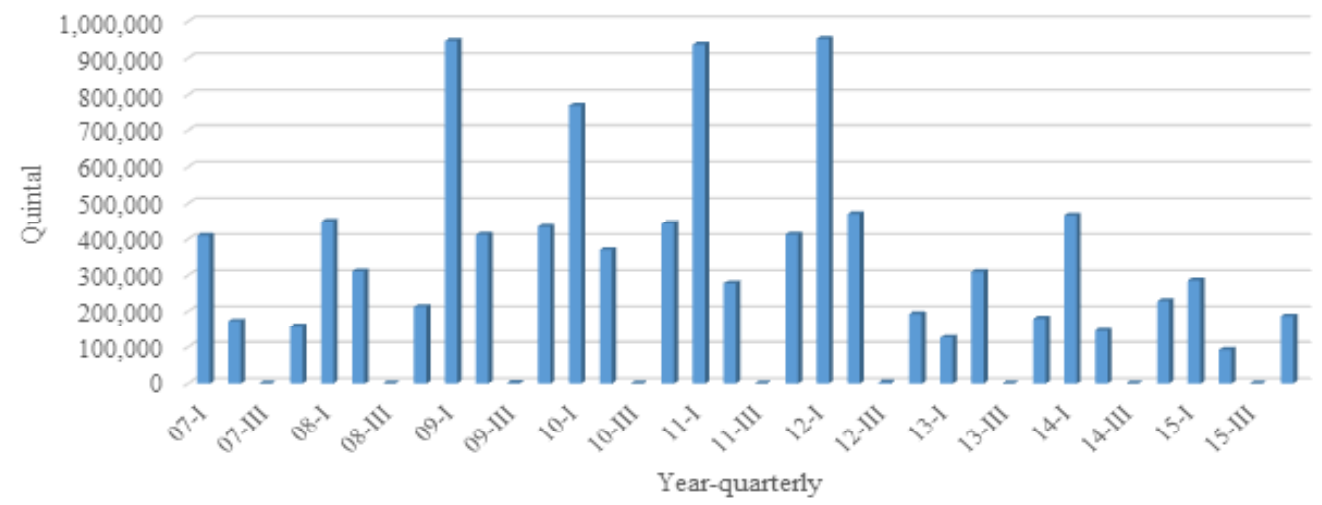

Figure 5. The development of citrus imports from China during 2007-2015 (Trademap, 2016) 


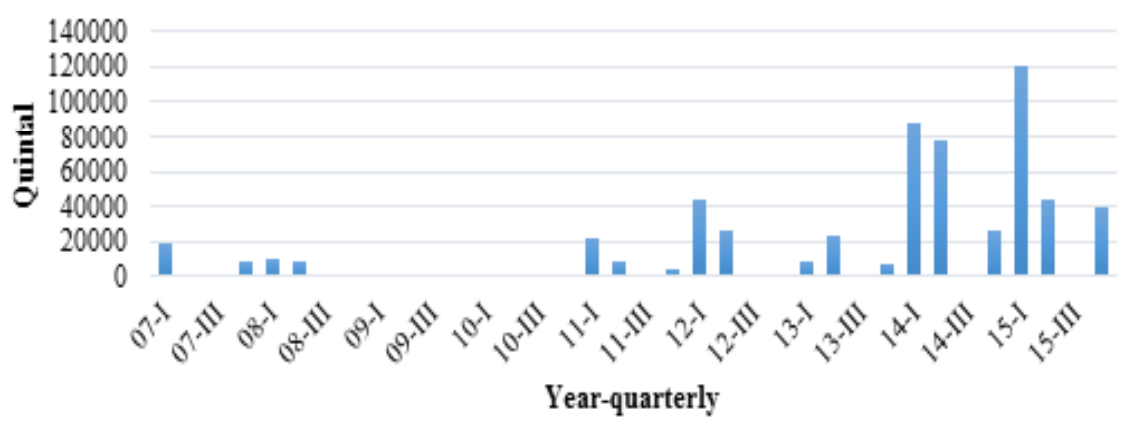

Figure 6. The development of citrus imports from Pakistan during 2007-2015 (Trademap, 2016)

\section{Level of Local Orange Relief (Siam/Keprok) with Imported Citrus}

The model used to describe the demand and competition system between local citrus and imported citrus in Indonesia was the model of Almost Ideal Demand System (AIDS). The model was used because the AIDS estimator model has the basic requirements of symmetry and homogenty, while the add-up properties have been met automatically in the alleged model of AIDS (Deaton and Muellbauer, 1980).

\section{Parameter Estimation of Demand System Model}

The estimation result of demand system model for local orange and imported oranges in Indonesia is presented in Table 1. Based on table 1 above, $R$ square values for each model of AIDS respectively 44. 92\% for local oranges (Indonesia), $48.23 \%$ for Chinese oranges and $46.73 \%$ for Pakistani oranges. These values show the ability to explain the independent variables on the diversity of the value of the proportion (share) of a country's citrus. In addition, the significant $\mathrm{p}$-value $\mathrm{F}$ (statistics) of the Indonesian model at $5 \%(0.0000<0.05)$ indicates that these independent variables can simultaneously explain the variables of the proportion/share of local ranges of Indonesia. Also, the Chinese and Pakistani models show $p$-value of $<0.05$ which means all models can explain the variable of proportion/share of oranges in Indonesian market. According to Gheblawi et al. (2013), AIDS model that has an insignificant p-value can lead to the usual interpretation. The regression coefficients of the predicted result with the AIDS model are then used to calculate the self-elasticity value using the uncompensated elasticity formula and cross-price elasticity values using the compensated elasticity formula.

\section{Estimated Demand Elasticity}

The sensitivity of the quantity response of a commodity demand to the various changes such as price and income is an important factor that must be understood in economics. The level of sensitivity or elasticity can be an important information for the economic actors i.e. producers; consumers and governments in making a decision. There are three forms of elasticity discussed in this research including the expenditure elasticity, own elasticity and cross elasticity.

The result of the study shows that the largest average orange share is from Indonesia (local oranges) of $93.10 \%$, indicating that the local production of oranges is high. However, in terms of price and quality, both local oranges and imported oranges can compete. Hanif and Zamzami (2012) revealed that nowadays, it is a fact that imported citrus are more easily found in supermarkets and even in retail traders than in traditional markets and street vendors.

The second market share was occupied by China with an average market share of oranges reaching $6.10 \%$. Pakistan shows a relatively small average market share $(0.3 \%)$, and this is because Pakistan just began to increase its imports in 2012 (the PTA is between Indonesia and Pakistan) (Figure 7).

\section{a) Elasticity of Expenditure}

The elasticity of expenditure is the response of changes in the market share of each country's orange supply to changes in total of expenditure (import value plus domestic production). Table 2 shows that Indonesia has an expenditure elasticity value of 1.026 which means that if there is a case of an increase of Indonesian orange 
expenditure total by 1 percent, the expenditure will increase local demand for oranges by 1.026 percent. China and the rest of the world have positive marked elasticity values while, the elasticity of expenditure for oranges from Pakistan was negative (3.323). Chang and Nguyen (2002) revealed that the individual expenditure coefficients may not have the usual interpretations or expected signs. This can happen because the Pakistani oranges are classified as having lower quality and lower prices. Malik and Khan (2014) point out that for the last decade, the quality of the display from Kino has worsened where the skin blemishes. It is important to understand that although skin blemishes do not significantly affect fruit taste quality, the international market value of fresh fruit decreases and exporters do not wish to buy the fruit.

\section{b) Own Price Elasticity}

Own price elasticity shows changes in the number of requests resulting from price changes. The three countries show the negative values of elasticity where the response to changes in price increases, it will decrease the market share of citrus from each country as presented in the Table 3 . In terms of the estimation result, the interesting thing is that the price of orange own elasticity of Pakistan is negative by 10.15 . This means that if there is a self-price increase by 1 percent, it will reduce the demand for import of oranges from Pakistan by $10.15 \%$. This pointed out that the response to changes in demand for Pakistani orange prices is very high (elastic), reinforcing the notion that oranges from Pakistan are of low quality.

Mahmood and Seikh (2006); Sultan (2015) revealed that the problems related to the process of exporting orange products from Pakistan include low quality of oranges, lack of storage facilities, unavailability of quality packaging, and poor transportation facilities. The low quality of oranges from Pakistan has experienced a number of rejections from the exporters (Malik and Khan, 2014).

\section{c) Cross Price Elasticity}

Competition between local and imported oranges is reflected in the value of cross-price elasticity of each commodity. The mutual substitution relationship is exchanged between imported oranges originating from China and local oranges production in Indonesia.

The value of cross elasticity value between them is 0.06 which means that when the price of the oranges from China decreases, the orange origin country will decrease the local citrus market share (Indonesian share) (Table 4). This is consistent with the initial hypothesis that imported orange are the competitor of local oranges. In the case of an increase in local citrus prices, it will increase the market share of citrus imports in Indonesia. It is in line with the results of Selae et al. (2002) where imported products are a competitor of local production.

Table 1. The result of model estimation of the level of competition between local oranges and imported oranges

\begin{tabular}{lcccccc}
\hline \multirow{2}{*}{$\begin{array}{c}\text { Independent } \\
\text { Variable }\end{array}$} & \multicolumn{2}{c}{ Indonesia } & \multicolumn{2}{c}{ Cina } & \multicolumn{2}{c}{ Pakistan } \\
\cline { 2 - 7 } & coefisien & P-value & coefisien & P-value & coefisien & P-value \\
\hline Indonesia Price & 0.0087 & 0.787 & -0.0030 & 0.923 & -0.0055 & 0.179 \\
Cina Price & -0.0030 & 0.923 & 0.0263 & 0.427 & $-0.0303^{* *}$ & 0.002 \\
Pakistan Price & -0.0055 & 0.179 & $-0.0303^{* *}$ & 0.002 & $0.0347^{* *}$ & 0.000 \\
ROW Price & -0.0002 & 0.944 & 0.0070 & 0.144 & 0.0010 & 0.778 \\
X Price & 0.0243 & 0.486 & -0.0099 & 0.772 & $-0.0145^{* *}$ & 0.001 \\
Tw-3 & $0.0540^{* *}$ & 0.007 & $-0.0521^{* *}$ & 0.008 & $-0.0068^{* *}$ & 0.008 \\
Chinese New Year & $-0.0360^{* *}$ & 0.046 & $0.0410^{* *}$ & 0.021 & -0.0028 & 0.203 \\
C & 0.4464 & 0.525 & 0.2430 & 0.724 & $0.3067^{* *}$ & 0.000 \\
& R-sq & 0.4492 & R-sq & 0.4823 & R-sq & 0.4673 \\
& P-value & 0.0000 & P-value & 0.0000 & P-value & 0.0000 \\
\hline
\end{tabular}

Notes: Pi: local orange price; Pc: Chinese orange price; Pp: Price of Pakistan orange; Pr: orange price of other countries (ROW); dan x: total orange expenditure of Indonesia; Significance at the real level: ** 5\% dan *10\% 


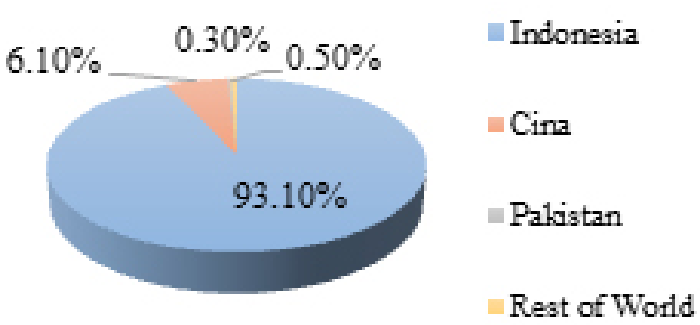

Figure 7. The average market share of oranges in Indonesia

Table 2. Estimated orange demand elasticity

\begin{tabular}{lc}
\hline \multicolumn{1}{c}{$\begin{array}{c}\text { Citrus supplier in } \\
\text { Indonesia }\end{array}$} & $\begin{array}{c}\text { Elasticity of expenditure } \\
\text { Indonesia }\end{array}$ \\
\hline Indonesia & 1.026 \\
Cina & 0.838 \\
Pakistan & -3.366 \\
Rest of World & 1.011 \\
\hline
\end{tabular}

Table 3. Estimate the price elasticity itself

\begin{tabular}{lc}
\hline $\begin{array}{c}\text { Citrus supplier country in } \\
\text { Indonesia }\end{array}$ & Self-elasticity \\
\hline Indonesia & -0.06 \\
Cina & -0.51 \\
Pakistan & -10.15 \\
\hline
\end{tabular}

Table 4. Self-Elasticity

\begin{tabular}{lc}
\hline \multicolumn{1}{c}{ Negara } & Indonesia \\
\hline Cina & 0.06 \\
\hline Pakistan & -0.003 \\
\hline
\end{tabular}

Local orange prices continue to increase, along with the increase in local orange prices. When China's orange imports continue to increase, local citrus production decreases. It proves that imported oranges from China are competitors of the local oranges.

Figure 8 explains that in 2013 the price of imported oranges from China was very high due to pest attacks on citrus crops so that during the harvest time the production of oranges in China decreased, resulting in the high price of its oranges.
Increasing local citrus prices also do not provide much profit to domestic producers because the margin received is spent more on the local orange marketing process. It is worth noting for the government in an effort to protect producers and increase the benefits of local oranges by considering not only at competitions among the imported oranges but also the marketing efficiency of the local oranges themselves.

\section{Managerial Implication}

Based on the results of competition analysis between local oranges and imported oranges by Almost Ideal Demand System method, there are several policy evaluations that need to be considered in order to increase local citrus production and have the competitiveness to be developed towards export:

\section{Import timing policy}

Free trade agreements between Indonesia-China and Indonesia-Pakistan by reducing import duties are not responded too much to the increase of imported orange share in Indonesia considering the values of cross elasticity for both China and Pakistan are very small (inelastic). However, in this case Indonesia has implemented a policy to restrain the growth of citrus imports. The policy includes the import of horticultural products in the Regulation of the Minister of Trade of the Republic of Indonesia No. 16 of 2013, then the restriction on the import of horticultural products as stipulated in the Minister of Agriculture Regulation Act No.86 of 2013, which is a government effort to protect the producers of horticultural products in Indonesia, one of which is local citrus producers. Haq (2015) said that import control policy on horticultural products will have a positive impact on citrus producers and consumers in Indonesia. For citrus producers the policy implications will increase the production of citrus, farmer exchange rate, local fruit image. As for the consumers, the advantages include food security, product availability, and orange quality. Coulibaly et al. (2015) assumes that it is important for the government not only consider the price attributes in responding to competition with imported products, but also the quality of local products that must be increased in order to compete with imported products. 


\section{Increased local citrus production}

The result of expenditure elastic analysis shows that local oranges are most responsive to changes in the total amount of Indonesian orange expenditure. Therefore, the most appropriate policy is to increase the production of local oranges where there is still an opportunity to increase the consumption needs of citrus Indonesia. According to the World Food Program (FAO) recommended in Young (2005) the standard consumption of fruits is at least $65.75 \mathrm{~kg} /$ per year, while the average consumption of Indonesian population in fruits currently only reaches $40 \mathrm{~kg}$ per capita per year. Therefore, it is possible to increase the level of consumption of oranges per capita. The opportunity must be supported by local citrus production because with the increase of orange consumption in Indonesia, the local citrus market will increase and suppress the increase of the market share of imported citrus.

\section{Marketing efficiency}

The competition analysis shows that local Indonesian oranges compete with imported oranges from China where the decline of imported orange price from China will decrease the share of Indonesia (local oranges). In fact, local orange prices at the consumer level continue to increase almost every year, which can reduce the demand for local oranges and can reduce the local citrus market share in Indonesia. The high price of citrus at the consumer level does not make the price at the producer level also high. This is what causes the decline of interest of farmers to farm oranges. In addition, the gap in price is too high between the prices at the producer level and the consumer price level which indicates the lack of efficiency in the local orange distribution process from the production center to the consumer center.

Therefore, marketing efficiency can be conducted starting from building a good information system network at the farm level, one of which is by forming farmer groups. The use of information technology at the farm level can help farmers in terms of access to information related to cultivation technology, weather climate, and pricing information.

In addition, efficiency can be achieved through the development of product quality assurance, improvement of marketing efficiency and product promotion, improvement of physical infrastructure and market institutions. In addition to efforts in increasing domestic citrus market share, it is also expected that local Indonesian citrus can enter the export market so that local citrus production will continue to increase. Asikin et al. (2016) stated that factors affecting export performance in Indonesia include transportation infrastructure, information communication technology, and institutions. Improvement of these variables will have a positive effect on the performance of product exports from Indonesia.

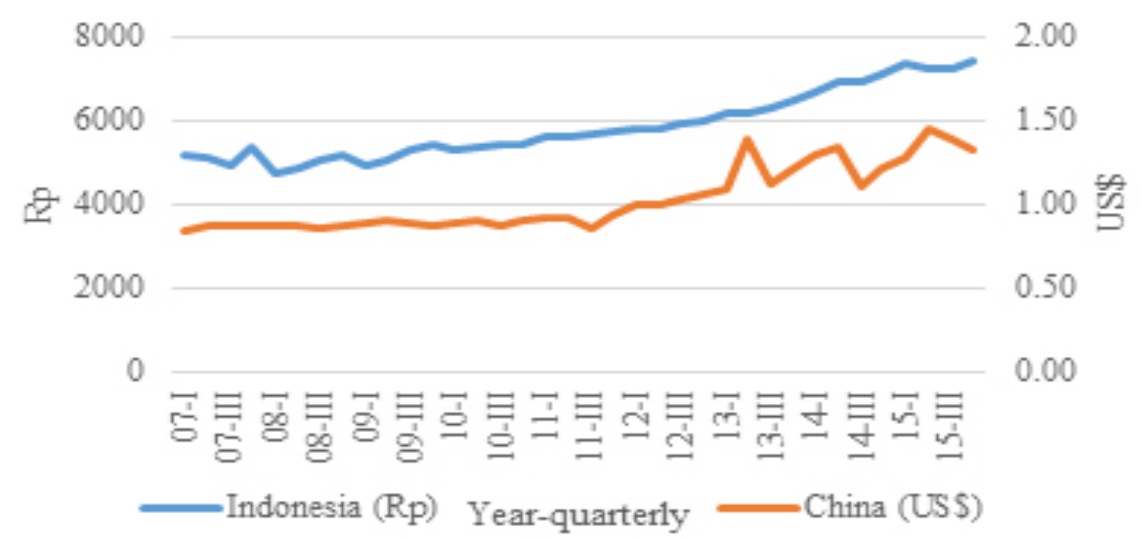

Figure 8. The development of local oranges prices and imported oranges from China 


\section{CONCLUSIONS AND RECOMMENDATIONS}

\section{Conclusions}

The elasticity calculations from the AIDS model indicate that local Indonesian oranges compete with imported oranges from China, as shown by the value of positive cross elasticity (substitution). Indonesia needs to conduct a local orange marketing efficiency so that consumer prices can compete with the price of imported oranges from China so that they can suppress the increase of imported orange market from China.

The elasticity of Indonesia's expenditure on citrus (the value of citrus imports plus the value of local citrus production) is prosperous and the highest so Indonesia needs to increase local citrus production to meet the increasing demand for citrus, thus the Indonesian orange market will increase higher than that of the Chinese and Pakistan orange markets.

\section{Recommendations}

On the domestic policy side, the first thing the government should fix is the availability of national orange data. So far, the data on the local citrus both its production and consumption needs in the country are still unreliable. Currently, the available data only include the number of national citrus production from each citrus-producing centers in Indonesia while the proportion of oranges for household consumption and for industrial needs has not been separated.

\section{REFERENCES}

Asikin Z, Daryanto A, Lukytawati A. 2016. Pengaruh infrastruktur dan kelembagaan terhadap kinerja eksporagregat dan sektoral Indonesia. Jurnal Manajemen \& Agribisnis 13(1): 145-156. https://doi.org/10.17358/JMA.13.2.145.

Chang H, Nguyen C. 2002. Elasticity ofdemand for Australian cotton in Japan. The Australian Journal of Agricultural and Resource Economics 46: 99-113. https://doi.org/10.1111/14678489.00169 .

Coulibaly JY, Tebila N, Diagne A. 2015. Reducing rice imports in Cote d'ivoire: is a rise in import tariff the solution?.Agricultural and Resource Economics Review 44(3):195-213. https://doi. org/10.1017/S1068280500005025.
Deaton A, Muellbauer J. 1980. An almost ideal demand system. American Economic Review 70(3): 312325.

Destriani RP, Jamil AS, Tinaprilla N. 2015. The demand and competition among supply source in Indonesia meat import market. Di dalam: Nunung Kusnadi. Seminar Nasional: Kristalisasi paradigma Agribisnis dalam Pembangunan Ekonomi dan Pendidikan Tinggi.Bogor, 18 April 2015. Bogor: Departemen Agribisnis, Fakultas Ekonomi dan Manajemen-IPB. 455-467.

[Ditjen Hortikultura] Direktorat Jenderal Hortikultura Kementrian Pertanian. 2016. Laporan Realisasi ATAP Produksi Jeruk Siam/Keprok Indoensia. Jakarta: Kementrian Pertanian.

Firdaus M. 2005. Potret impor buah Indonesia. AGRIMEDIA 10(1): 28-43.

Gheblawi MS, Alashry MK, Sherif S, Basarir A, U1Haq Z. 2013. Analyzing UAE's imports of fresh fruits utilizing an almost ideal demand system. Bulgarian Journal of Agricultural Science. 19(4): 792-800.

Hanif Z, Zamzami L. 2012. Trend jeruk impor dan posisi Indonesia sebagai produsen jeruk dunia. http://balitjestro.litbang.pertanian.go.id/trendjeruk-impor-dan-posisi-indonesia-sebagaiprodusen-jeruk-dunia/. [1 Oktober 2013].

Hatab AA, Romstad E. 2013. Competitiveness analysis of Egyptian cotton expor ts with special focus on the Chinese market. China Agricultural Economic Review 6(2):248-263.doi: 10.1108/ CAER-02-2013-0026.

Haq N. 2015. Implikasi kebijakan pembatasan impor hortikultura Indonesia pasca penandatanganan preferential trade agreement (pta) dengan pakistan tahun 2012. Jurnal Online Mahasiswa (JOM) Bidang Ilmu Sosial dan Ilmu Politik 2(2): $1-12$.

Hui J, Couvillion W, McLean MP. 1996. Empirical evidence of competition in Japan's raw cotton market: implications for US cotton exports. Agribusiness 12(1):175-81. https://doi.org/10.1002/(SICI)15206297 (199603/04)12:2<175:: A ID AGR7>3.0.CO;2-\#.

Jamil AS. 2015. Analisis permintaan impor garam Indonesia. [tesis]. Bogor: Sekolah Pascasarjana, Institut Pertanian Bogor.

[Kementan] Kementrian Pertanian. 2015. Rencana Strategis Kementrian Pertanian Tahun 20152019. Indonesia: Kementrian Pertanian Republik 
Indonesia.

Mahmood MA, Seikh AD. 2006. Citrus export system in Pakistan. Journal of Agricultural Research 44(3):229-238.

Malik AU, Khan IA. 2014. Kinnow Quality: Issues and Strategies for Improvement. Pakistan: University of Agriculture Faisalabad.

Nurchayati, Hikmah. 2014. Pola distribusi buah lokal dan buah impor: studi kasus pada pedagang buah di Kota Semarang. Serat Acitya - Jurnal Ilmiah UNTAG Semarang 3(1): 17-29.

Rifin A. 2013. Competitiveness of Indonesia's cocoa beans export in the world market. International Journal of Trade, Economies and Finance 4(5): 279-281. https://doi.org/10.7763/IJTEF.2013. V4.301.

Sayekti AL, Zamzami L. 2011. Analisis keunggulan komparatif dan kompetitif jeruk siam di sentra produksi. Widyariset 14(1): 1-10.
Seale JL, Marchant MA, Basso A. 2002. Imports versus domestic production: A demand system analysis of the U.S. red wine market. Review of Agricultural Economics 25(1): 187-202. https:// doi.org/10.1111/1467-9353.00053.

Sultan MF. 2015. Kinow: The popular orange from Pakistan. Exclusive on Orange 30-31.

[Trademap] Trade Statistics for International Business Development. 2016. List of Supplying Markets for a Product Imported by Indonesia. http://www. trademap.org/Country_SelProductCountry_TS .aspx?nvpm=1|360||||0805|||4|1|1|1|2|1|2|1|. [27 September 2016].

Yuliastuti AR, Dwiatuti R, Nuhfil H. 2014. Anlisis dinamis permintaan buah-buahan di Indonesia: pendekatan model error correction-linier approximation almost ideal demand system. AGRISE 16(3):238-256. 